\title{
Crystal structure of $\mathrm{NaCd}\left(\mathrm{H}_{2} \mathrm{PO}_{3}\right)_{3} \cdot \mathrm{H}_{2} \mathrm{O}$ and spectroscopic study of $\mathrm{NaM}\left(\mathrm{H}_{2} \mathrm{PO}_{3}\right)_{3} \cdot \mathrm{H}_{2} \mathrm{O}$,
}

\section{$\mathrm{M}=\mathrm{Mn}, \mathrm{Co}, \mathrm{Ni}, \mathrm{Zn}, \mathrm{Mg}$ and $\mathrm{Cd}$}

Rachid Ouarsal ${ }^{1}$, Mohammed Lachkar ${ }^{1}$, Michal Dusek ${ }^{2}$, Ester Barrachina Albert ${ }^{3}$, Juan Bautista Carda Castelló ${ }^{3}$ and Brahim El Bali ${ }^{1, *}$

${ }^{1}$ Laboratoire d'Ingénierie des Matériaux Organométalliques et Moléculaires, Unité Associée au CNRST (URAC 19), Faculté des Sciences,

Université Sidi Mohamed Ben Abdellah, B.P.1796 (Atlas), 30000 Fès, Morocco.

${ }^{2}$ Institute of Physics, Na Slovance 2, 18221 Praha 8, Czech Republic.

${ }^{3}$ Department of Inorganic and Organic Chemistry, Universitat Jaume I, Av. de Vicent Sos Baynat, s/n 12071 Castelló de la Plana, Spain.

*: Mailto: belbali@fso.ump.ma

\begin{abstract}
$\mathrm{NaCd}\left(\mathrm{H}_{2} \mathrm{PO}_{3}\right)_{3} \cdot \mathrm{H}_{2} \mathrm{O}$ was synthesized in solution and its structure was studied by single-crystal $\mathrm{X}$-ray diffraction. It crystallizes in the orthorhombic system (Pbca, $\mathrm{Z}=8$ ) with the cell parameters: $a=9.290(2) \AA, b=15.1236(23) \AA, c=15.0592(14) \AA$. Final residual factors $R / R_{w}$ are 0.0297/0.0790. Both $\mathrm{Na}^{+}$and $\mathrm{Cd}^{2+}$ are octahedrally coordinated, $\left[\mathrm{NaO}_{6}\right]$ and $\left[\mathrm{CdO}_{6}\right]$ share edges to form zigzag chains along [010], which are interconnected by $\mathrm{H}_{2} \mathrm{PO}_{3}$ pseudo-pyramids. The new compound integers the series of isostructural phosphites $\mathrm{NaM}\left(\mathrm{H}_{2} \mathrm{PO}_{3}\right)_{3} \cdot \mathrm{H}_{2} \mathrm{O}(\mathrm{M}=\mathrm{Mn}$, $\mathrm{Co}, \mathrm{Zn}$ and $\mathrm{Mg}$ ). IR and Raman spectroscopic studies show the bands confirming the presence of the phosphite $\mathrm{H}_{2} \mathrm{PO}_{3}{ }^{2-}$ anion in the whole series $\mathrm{NaM}\left(\mathrm{H}_{2} \mathrm{PO}_{3}\right)_{3} \cdot \mathrm{H}_{2} \mathrm{O}, \mathrm{M}=\mathrm{Mn}, \mathrm{Co}, \mathrm{Ni}, \mathrm{Zn}$,
\end{abstract}


$\mathrm{Mg}$ and $\mathrm{Cd}$. The UV-Vis spectroscopy was used for characterizing the d-d transitions of the transition.

The crystal structure of $\mathrm{NaCd}\left(\mathrm{H}_{2} \mathrm{PO}_{3}\right)_{3} \cdot \mathrm{H}_{2} \mathrm{O}$ can be described as a three-dimensional network made of edge-sharing $\left[\mathrm{NaO}_{6}\right]$ and $\left[\mathrm{CdO}_{6}\right]$ octahedrons, leading to zigzag chains along [010]. Cohesion inside and between these chains is further reinforced by the presence of $\mathrm{O}-\mathrm{P}-\mathrm{O}$ bridges of the $\left[\mathrm{H}_{2} \mathrm{PO}_{3}\right]$ units and a $\mathrm{P}-\mathrm{OH}_{-}{ }_{--} \mathrm{O}$ and $\mathrm{OwH}_{-}{ }_{-} \mathrm{O}(\mathrm{w}$ is water) hydrogen bonds network. The P-H bond is evidenced by the IR study of the series $\operatorname{NaM}\left(\mathrm{H}_{2} \mathrm{PO}_{3}\right)_{3} \cdot \mathrm{H}_{2} \mathrm{O}, \mathrm{M}=\mathrm{Mn}, \mathrm{Co}, \mathrm{Ni}, \mathrm{Cu}, \mathrm{Mg}$ and $\mathrm{Cd}$. Electronic spectra of the $\mathrm{Mn}, \mathrm{Co}$ and Ni complexes are reported and d-d transitions have been assigned.

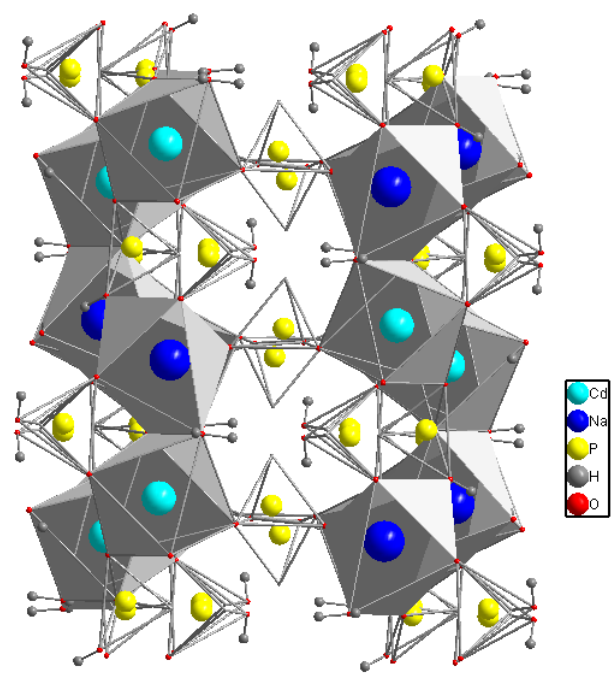




\section{Introduction}

Many crystal structures have been reported for such compounds in their simple form, i.e. $\mathrm{M}_{\mathrm{p}}\left(\mathrm{H}_{\mathrm{q}} \mathrm{PO}_{3} \mathrm{H}\right)_{\mathrm{r} .} \mathrm{xH} \mathrm{H}_{2} \mathrm{O}$ (p belonging $3 \mathrm{~d}$ or $4 \mathrm{~d}$ metal groups, $\mathrm{q}=1$ or $2, \mathrm{r}=2$ or 3 ) [1-16]. However, a bibliographic survey showed the presence of only few mixed phosphites with the chemical formula $\mathrm{AM}\left(\mathrm{H}_{2} \mathrm{PO}_{3}\right)_{3} \cdot \mathrm{H}_{2} \mathrm{O}$, where $\mathrm{A}$ is an alkaline metal and $\mathrm{M}$ is a $3 \mathrm{~d}$ divalent metal (including $\mathrm{Zn}$ ) or $\mathrm{Mg}$. Especially in the case of $\mathrm{A}=\mathrm{Na}$, the phases with Mn [17], Co [18] and Ni[19] are mentioned. We previously published the isostructural mixed phosphites $\mathrm{NaZn}\left(\mathrm{H}_{2} \mathrm{PO}_{3}\right)_{3} \cdot \mathrm{H}_{2} \mathrm{O}$ [20] and $\mathrm{NaMg}\left(\mathrm{H}_{2} \mathrm{PO}_{3}\right)_{3} \cdot \mathrm{H}_{2} \mathrm{O}$ [21], which are by turns also isostructural to $\mathrm{NaM}\left(\mathrm{H}_{2} \mathrm{PO}_{3}\right)_{3} \cdot \mathrm{H}_{2} \mathrm{O}, \mathrm{M}=\mathrm{Mn}$ [17], Co [18] and $\mathrm{Ni}$ [19], all of them crystallizing in the orthorhombic system (Pbca). Later, we also reported a new kind of such phosphates: $\mathrm{K}_{2} \mathrm{Co}\left(\mathrm{PO}_{3} \mathrm{H}\right)_{2} \cdot 2 \mathrm{H}_{2} \mathrm{O}$ [22], with a monoclinic symmetry $(\mathrm{C} 2 / \mathrm{m})$. Other mixed phosphites phases have been reported in the literature: $\mathrm{Na}_{2} \mathrm{M}\left(\mathrm{HPO}_{3}\right)_{2}(\mathrm{M}=$ $\mathrm{Fe}, \mathrm{Co})$ [23], $\mathrm{K}_{2} \mathrm{Mn}_{3}\left(\mathrm{HPO}_{3}\right)_{4}$ [24] and $\left(\mathrm{NH}_{4}\right)_{2} \mathrm{Co}_{2}\left(\mathrm{HPO}_{3}\right)_{3}$ [25]. As corrosion inhibitor application, we have already reported on application, as inhibitor for the corrosion of the steel in corrosive acidic medium, of $\mathrm{NaM}\left(\mathrm{H}_{2} \mathrm{PO}_{3}\right)_{3} \cdot \mathrm{H}_{2} \mathrm{O}, \mathrm{M}=\mathrm{Zn}$ [26] and $\mathrm{Mg}$ [27]. In the present paper, in order to continue the investigations on such phosphites, the synthesis, crystal structure and vibrational studies from $\mathrm{NaCd}\left(\mathrm{H}_{2} \mathrm{PO}_{3}\right)_{3} \cdot \mathrm{H}_{2} \mathrm{O}$ are studied, which is isostructural with the known $3 \mathrm{~d}$ divalent mixed phosphites in the series $\operatorname{AM}\left(\mathrm{H}_{2} \mathrm{PO}_{3}\right)_{3} \cdot \mathrm{H}_{2} \mathrm{O}$ [17-21]. The spectroscopic studies (IR, Raman and UV-Vis) of the phosphites $\mathrm{NaM}\left(\mathrm{H}_{2} \mathrm{PO}_{3}\right)_{3} \cdot \mathrm{H}_{2} \mathrm{O}, \mathrm{M}=\mathrm{Mn}, \mathrm{Co}, \mathrm{Ni}, \mathrm{Zn}, \mathrm{Mg}$ and $\mathrm{Cd}$ are also reported.

\section{Experimental}


II.1 Preparation of mixed phases of types $\mathrm{NaM}\left(\mathrm{H}_{2} \mathrm{PO}_{3}\right)_{3} \cdot \mathrm{H}_{2} \mathrm{O}$

Preparations of the phases $\mathrm{NaM}\left(\mathrm{H}_{2} \mathrm{PO}_{3}\right)_{3} \cdot \mathrm{H}_{2} \mathrm{O}$ with $(\mathrm{M}=\mathrm{Ni}, \mathrm{Zn}, \mathrm{Mg}$ or $\mathrm{Cd})$ as well as the already known phases $\mathrm{NaM}\left(\mathrm{H}_{2} \mathrm{PO}_{3}\right)_{3} \cdot \mathrm{H}_{2} \mathrm{O}$ with $(\mathrm{M}=\mathrm{Mn}$ [1] and $\mathrm{Co}$ [2], were made in two different ways:

\section{First way:}

$10 \mathrm{mmol}$ of metal chloride are added to $10 \mathrm{mmol}$ of sodium hydrogen phosphite dissolved in $20 \mathrm{ml}$ of $\mathrm{H}_{3} \mathrm{PO}_{3}$.

\section{Second way:}

Equimolar preparation of two solutions, one containing the solution of sodium dihydrogen phosphite and the other containing the solution of metal bisdihydrogenophosphite. The two solutions are mixed and heated with stirring for $3 \mathrm{~h}$ at $60{ }^{\circ} \mathrm{C}$.

After slow evaporation of the two solutions, rhombuses-shape crystals are obtained and washed with an ethanol-water (80-20\%).

These compounds have shown good crystallization and their identification was verified initially by X-ray powder which confirmed their isostructurality.

\section{II.2 Single crystal study}

The X-ray diffraction data for $\mathrm{NaCd}\left(\mathrm{H}_{2} \mathrm{PO}_{3}\right)_{3} \cdot \mathrm{H}_{2} \mathrm{O}$ were collected in a four-circles diffractometer Gemini of Oxford Diffraction (now Agilent Technologies), using graphite monochromatized MoK $\alpha$ radiation $(\lambda=0.7173 \AA)$ collimated with Mo-Enhance and an Atlas CCD detector. The intensity data were corrected for Lorentz and polarization effects. A numerical absorption correction based on the crystal shape was carried out with the program CrysAlis RED [28]. The structures were solved by the Direct Methods 
procedure of SIR97 [29] and refined by a full-matrix least-squares technique based on $\mathrm{F}^{2}$ with Jana2006 [30]. All non-hydrogen atoms were refined with anisotropic displacement parameters. Positions of hydrogen atoms belonging to water molecules were found in the difference Fourier map and refined with a restrain on their distance to the parent oxygen atom. Their isotropic temperature parameters were calculated as $1.2 \cdot \mathrm{Ueq}$ of the parent oxygen. Table 1 reports the crystallographic data and experimental details about data collection and structure refinements. Atomic coordinates and the equivalent thermal parameters are reported in Table 2, selected bond distances in Table 3. The structural graphics were created using DIAMOND program [31]. Supplementary tables of crystal structures and refinements, notably full list of bond lengths and angles, and anisotropic thermal parameters have been deposited with the Inorganic Crystal Structure Database, ICSD-deposition code \# 421377 with FIZ, Hermann von Helmholtz Platz 1, 76344 Eggenstein-Leopoldshafen, Germany; fax: +49 7247808 132; Email: crysdata@fiz-karlsruhe.de. 


\section{II.3 Infrared spectrum}

Infrared spectrum of the title compound was recorded, as suspension powder in $\mathrm{KBr}$, on a Perkin-Elmer Spectrometer 1750, in the range $350-4000 \mathrm{~cm}^{-1}$.

\section{II.4 Raman spectroscopy}

Raman spectra were measured in a back scattering arrangement at room temperature and pressure by using a high-through put holographic imaging spectrograph with volume transmission grating, holographic notch filter and thermoelectrically cooled CCD detector (Physics Spectra), and a resolution of $4 \mathrm{~cm}^{-1}$. The spectrometer was regularly calibrated by using the neon lines. $\mathrm{Ti}^{3+}$-sapphire laser pumped by an argon ion laser was tuned at $785 \mathrm{~nm}$. Table 7 reports the bands assignments for the IR and Raman spectra.

FTIR spectra were acquired from 600 to $4000 \mathrm{~cm}^{-1}$ on a JASCO 6200 equipment with a MIRacle single-reflection ATR diamond / ZnSe accessory. The raw IR spectra data were processed with the JASCO spectral manager software.

\section{II.5 UV-Visible}

UV-visible spectroscopy of the samples was measured using a Cary 500 Scan Varian spectrophotometer in the $11111-40000 \mathrm{~cm}^{-1}$ range (step absorption spectra were obtained using $\mathrm{BaSO}_{4}$ integrating sphere as a white reference material. The interpretation and attribution of these spectra are realised on the basis of d-d transitions using the TanabéSugano diagrams. The calculation of the Racah parameters Dq and B were done using the equation described by Reedijk [32]. 


\section{Discussion}

\section{III.1 Structure description}

The crystal structure of $\mathrm{NaCd}\left(\mathrm{H}_{2} \mathrm{PO}_{3}\right)_{3} \cdot \mathrm{H}_{2} \mathrm{O}$ is built up from edge sharing $\left[\mathrm{NaO}_{6}\right]$ and $\left[\mathrm{CdO}_{6}\right]$ octahedral, running in a form of zigzag channels along [100]. These chains are interconnected via O-P-O bridges from $\mathrm{H}_{2} \mathrm{PO}_{3}$ phosphite groups. Fig. 1 depicts the projection of the new structure on the ac plane. The cohesion of the chains is moreover reinforced by an intricate network of weak hydrogen bonds between the water oxygen and the hydroxyl group in $\mathrm{H}_{2} \mathrm{PO}_{3}$.

The octahedral chains are cross-linked by the phosphite moieties: the P1-centred group links adjacent chains in the $\mathrm{b}$ direction, and the P3 group fuses the chains in the [100] direction, while the P2-centered group acts in both directions (Fig.1 \& 2). The structure is also stabilized by the hydrogen bonds $\mathrm{P}-\mathrm{OH} \ldots . . \mathrm{O}$ and $\mathrm{O}_{\mathrm{w}} \mathrm{H} \ldots . . \mathrm{O}$ (w for water). These hydrogen bonds interactions have been previously described by Chmelikova et al. in $\mathrm{NaMn}\left(\mathrm{H}_{2} \mathrm{PO}_{3}\right)_{3}, \mathrm{H}_{2} \mathrm{O}[17]$.

Phosphorous atoms occupy three non-equivalent crystallographic positions in the two new isotypic structures. Average P-O distance 1.5240(4) $\AA$ and P-H distances, which are: $\mathrm{P} 1-\mathrm{H} 6=1.34(3) \AA, \mathrm{P} 2-\mathrm{H} 7=1.27(4) \AA \mathrm{P} 3-\mathrm{H} 2=1.37(3) \AA$ are to compare to the measured values in the isoformular compounds: $\mathrm{NaCo}\left(\mathrm{H}_{2} \mathrm{PO}_{3}\right)_{3} \cdot \mathrm{H}_{2} \mathrm{O}(1.537 \AA ̊ .1 .27 \AA ̊)$

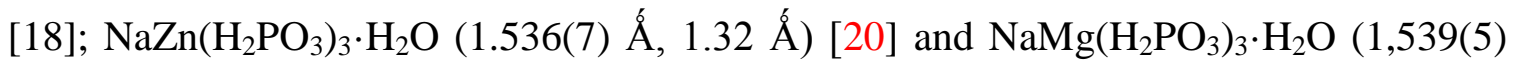
Á, 1.26(6) Á) [21]. Notice that $\mathrm{H}$ atom bonded to phosphorus atom is not involved in any hydrogen bonding. On the contrary, the water molecules $\mathrm{H}$ interact with the $\mathrm{O}$ from phosphates group to build an H-bonds network. Strongest H-bonds are reported in Tab. 4. 
The cation $\mathrm{Cd}^{+2}$ is octahedrally coordinated by five oxygen atoms from $\mathrm{HPO}_{3} \mathrm{H}$ groups, acting as monodentate, with an average $\mathrm{d}_{\mathrm{Cd}-\mathrm{O}}=2.267(2) \AA$. The sixth oxygen atom "O10" belongs the water molecule, at 2.366(2) $\AA$. Overall average $\mathrm{d}_{\mathrm{av}} \mathrm{Cd}-\mathrm{O}=2.284(2) \AA$ is of the same magnitude as shown in $\mathrm{Cd}\left(\mathrm{HPO}_{3} \mathrm{H}\right)_{2} \cdot \mathrm{H}_{2} \mathrm{O}, 2.278$ to $2.331 \AA$ [8].

Alike $\mathrm{Cd}^{+2}, \mathrm{Na}^{+}$adopts the same coordination scheme. Average Na-O distance is $2.434(4)$ $\AA$, which is similar as the ones reported in the isostructural phosphites: $\operatorname{NaMn}\left(\mathrm{HPO}_{3} \mathrm{H}\right)_{3} \cdot \mathrm{H}_{2} \mathrm{O}, \quad 2.442 \quad \AA \quad \quad[17] ; \mathrm{NaCo}\left(\mathrm{HPO}_{3} \mathrm{H}\right)_{3} \cdot \mathrm{H}_{2} \mathrm{O}, \quad 2.443 \quad \AA \quad \quad[18] ;$ $\mathrm{NaZn}\left(\mathrm{HPO}_{3} \mathrm{H}\right)_{3} \cdot \mathrm{H}_{2} \mathrm{O}, 2.452(2) \AA ̊\left[\right.$ [20] and $\mathrm{NaMg}\left(\mathrm{HPO}_{3} \mathrm{H}\right)_{3} \cdot \mathrm{H}_{2} \mathrm{O}, 2.446 \AA$ [21]. In Fig. 3 it is drawn the metal coordination in $\mathrm{NaCd}\left(\mathrm{H}_{2} \mathrm{PO}_{3}\right)_{3} \cdot \mathrm{H}_{2} \mathrm{O}$.

\section{III.2 Vibrational Spectroscopy}

\section{III.2.1 Factor Group Analysis}

The compounds $\mathrm{NaM}\left(\mathrm{H}_{2} \mathrm{PO}_{3}\right)_{3} \cdot \mathrm{H}_{2} \mathrm{O}(\mathrm{M}=\mathrm{Mn}, \mathrm{Co}, \mathrm{Ni}, \mathrm{Zn}$ and $\mathrm{Mg})$ crystallize in the orthorhombic system with space group Pbca $\left(\mathrm{D}_{2 \mathrm{~h}}\right), \mathrm{Z}=8$. Group theoretical analysis using the standard correlation method [33], gives $549(3 \mathrm{~N} \times \mathrm{Z}-3)$ normal modes of vibrations, exclusive of the three acoustic modes (Table 5). They are distributed as $69 \mathrm{Ag}(\mathrm{Ra})+$ $69 B 1 g(R a)+69 B 2 g(R a)+69 B 3 g(R a)+69 A u(I R)+68 B 1 u(I R)+68 B 2 u(I R)+68$ $\mathrm{B} 3 \mathrm{u}(\mathrm{IR})$. All the atoms are lying on the $\mathrm{C} 1$ sites. In these salts, the internal modes of the $\mathrm{HPO}_{3}{ }^{2-}$ ion and those of the water molecules in this compound are given respectively by the correlation schemes in Tables $6 \mathrm{a} \& \mathrm{~b}$. The factor group analysis notified the distribution of the irreducible representation of the internal modes of $\mathrm{HPO}_{3}{ }^{2-}$ anions and $\mathrm{H}_{2} \mathrm{O}$ molecules in $\mathrm{NaM}\left(\mathrm{H}_{2} \mathrm{PO}_{3}\right)_{3} \cdot \mathrm{H}_{2} \mathrm{O}$ compounds to be as follows: 
$\Gamma\left(\mathrm{HPO}_{3}{ }^{2-}\right)=27 \mathrm{Ag}(\mathrm{Ra})+27 \mathrm{~B} 1 \mathrm{~g}(\mathrm{Ra})+27 \mathrm{~B} 2 \mathrm{~g}(\mathrm{Ra})+27 \mathrm{~B} 3 \mathrm{~g}(\mathrm{Ra})+27 \mathrm{Au}(\mathrm{IR})+27 \mathrm{Bu}$

$(\mathrm{IR})+27 \mathrm{~B} 2 \mathrm{u}(\mathrm{IR})+27 \mathrm{~B} 3 \mathrm{u}(\mathrm{IR})$.

$\Gamma\left(\mathrm{H}_{2} \mathrm{O}\right)=3 \mathrm{Ag}(\mathrm{Ra})+3 \mathrm{~B} 1 \mathrm{~g}(\mathrm{Ra})+3 \mathrm{~B} 2 \mathrm{~g}(\mathrm{Ra})+3 \mathrm{~B} 3 \mathrm{~g}(\mathrm{Ra})+3 \mathrm{Au}(\mathrm{IR})+3 \mathrm{Bu}(\mathrm{IR})+$

$3 \mathrm{~B} 2 \mathrm{u}(\mathrm{IR})+3 \mathrm{~B} 3 \mathrm{u}(\mathrm{IR})$.

\section{III.2.2 Infrared spectroscopy}

The IR spectra from the series $\mathrm{NaM}\left(\mathrm{H}_{2} \mathrm{PO}_{3}\right)_{3} \cdot \mathrm{H}_{2} \mathrm{O}(\mathrm{M}=\mathrm{Mn}, \mathrm{Co}, \mathrm{Ni}, \mathrm{Mg}, \mathrm{Zn}$ and $\mathrm{Cd})$ are depicted in Fig. 4a\&b. The wavenumbers, relative intensities and the assignments of the bands observed are listed in Table 7. Spectra are interpreted on the basis of the hydrogenphosphite ion $\mathrm{HPO}_{3} \mathrm{H}^{-}$. In fact, in these spectra, characteristic bands of vibrations stretching of $\mathrm{v} \mathrm{P}-\mathrm{H}$ are observed in the region $2350-2450 \mathrm{~cm}^{-1}$, and the vibration bending $\delta \mathrm{P}-\mathrm{H}$ appears at 1030 to $998 \mathrm{~cm}^{-1}$ in IR spectrum. Bands assigned to the stretching vibration of the $\mathrm{P}-\mathrm{OH}$ are located to frequencies of $910 \pm 10 \mathrm{~cm}^{-1}$. Vibrational bands at 420, 570, 1050 and $1160 \mathrm{~cm}^{-1}$ are characteristic for a $\mathrm{PO}_{3}$ group. The vibrational modes at 1630 and $3440 \mathrm{~cm}^{-1}$ are assigned to the symmetric and asymmetric vibrations of the water molecule. The IR anomaly in $\mathrm{NaMg}\left(\mathrm{H}_{2} \mathrm{PO}_{3}\right)_{3} \cdot \mathrm{H}_{2} \mathrm{O}$, which shows approximately the same bands as the other compounds but presenting a higher signal in each band, might be related to the size difference with other $3 \mathrm{~d}^{+2}$-metals. In fact, the size is a key role for hydration and complexation. That is, in the coordination to $\mathrm{Mg}$ ions, the phosphite complexing ligand interacts with $\mathrm{Mg}^{+2}$ from outside the primary hydration sphere around it, and does not replace the hydrating $\mathrm{H}_{2} \mathrm{O}$ molecules. 


\section{III.2.3UV-Vis spectroscopy}

UV-Vis absorption spectra of the phosphites $\mathrm{NaM}\left(\mathrm{H}_{2} \mathrm{PO}_{3}\right)_{3} \cdot \mathrm{H}_{2} \mathrm{O}(\mathrm{M}=\mathrm{Mn}, \mathrm{Co}$ and $\mathrm{Ni})$ are discussed and assignments and deduced Racah parameters calculations are summarized in Table 8.

\section{Mn(II)-complex}

Figure 5a reports the electronic spectrum of the $\mathrm{Mn}(\mathrm{II})$ complex which exhibits weak intensity absorption bands with maxima at $\mathrm{v}_{1}: 18662 \mathrm{~cm}^{-1}, \mathrm{v}_{2}: 22866 \mathrm{~cm}^{-1}, \mathrm{v}_{3}: 24907 \mathrm{~cm}^{-}$ ${ }^{1}, v_{4}: 28033 \mathrm{~cm}^{-1}$ and $v_{5}: 35638 \mathrm{~cm}^{-1}$. Due to the forbidden d-d transitions, these transitions are weak, they may be assigned to transitions: v1: ${ }^{6} \mathrm{~A}_{1 \mathrm{~g}} \rightarrow{ }^{4} \mathrm{~T}_{1 \mathrm{~g}}(\mathrm{G}), \mathrm{v} 2:{ }^{6} \mathrm{~A}_{1 \mathrm{~g}}$ $\rightarrow{ }^{4} \mathrm{~T}_{2 \mathrm{~g}}(\mathrm{G}), \mathrm{v} 3:{ }^{6} \mathrm{~A}_{1 \mathrm{~g}} \rightarrow{ }^{4} \mathrm{~A}_{1 \mathrm{~g}}(\mathrm{G}),{ }^{4} \mathrm{E}_{\mathrm{g}}(\mathrm{G}), \mathrm{v} 4:{ }^{6} \mathrm{~A}_{1 \mathrm{~g}} \rightarrow{ }^{4} \mathrm{~T}_{2 \mathrm{~g}}(\mathrm{D})$ and $\mathrm{v} 5:{ }^{6} \mathrm{~A}_{1 \mathrm{~g}} \rightarrow{ }^{4} \mathrm{E}_{\mathrm{g}}(\mathrm{D})$. Use of Tanabe-Sugano diagram for $\mathrm{d}^{5}$ allows calculation of Dq knowing B [34], In fact, in the first transition $v_{1} / \mathrm{B}=24.89 \approx 25$ where $\mathrm{B}=750 \mathrm{~cm}^{-1}$. These assignments are compared with those published for octahedral geometry in $\mathrm{Mn}\left(\mathrm{HPO}_{3}\right)$ [35], or even in pyrophosphates like $\mathrm{Mn}_{2} \mathrm{P}_{2} \mathrm{O}_{7}$ [36] or $\mathrm{Cs}_{2} \mathrm{MnP}_{2} \mathrm{O}_{7}$ [37].

\section{Co(II)-complex}

$\mathrm{d}^{3}$ and $\mathrm{d}^{7}$ give rise to the same type and number of terms. In an octahedral ligand field, we will have again to deal with the ${ }^{4} \mathrm{~A}_{2 \mathrm{~g}},{ }^{4} \mathrm{~T}_{2 \mathrm{~g}},{ }^{4} \mathrm{~T}_{1 \mathrm{~g}}$, and ${ }^{4} \mathrm{~T}_{1 \mathrm{~g}}$ states. The ground state of octahedral $\mathrm{d}^{7}$ systems is $\mathrm{T}_{1 \mathrm{~g}}$ state, which is similar to the $\mathrm{d}^{2}$ case as long as $10 \mathrm{Dq}<(4 \mathrm{~B}+$ 4C) (high-spin ground state). However, the experimentally observed spin-allowed transitions are, in order of increasing energy, ${ }^{4} \mathrm{~T}_{1 \mathrm{~g}}{ }^{4} \mathrm{~T}_{2 \mathrm{~g}},{ }^{4} \mathrm{~T}_{1 \mathrm{~g}}{ }^{4} \mathrm{~A}_{2 \mathrm{~g}}$, and the transitions are denoted $v_{1}, v_{2}$, and $v_{3}$. Effectively the electronic spectrum of purple Co(II) complex (Fig. 5b) shows three absorption bands at 7215, 14451 and $18797 \mathrm{~cm}^{-1}$. These bands may be 
assigned respectively to ${ }^{4} \mathrm{~T}_{1 \mathrm{~g}}(\mathrm{~F}) \rightarrow{ }^{4} \mathrm{~T}_{2 \mathrm{~g}}(\mathrm{~F})\left(\mathrm{U}_{1}\right),{ }^{4} \mathrm{~T}_{1 \mathrm{~g}}(\mathrm{~F}) \rightarrow{ }^{4} \mathrm{~A}_{2 \mathrm{~g}}(\mathrm{~F})\left(\mathrm{U}_{2}\right)$ and ${ }^{4} \mathrm{~T}_{1 \mathrm{~g}}(\mathrm{~F}) \rightarrow$ ${ }^{4} \mathrm{~T}_{2 \mathrm{~g}}(\mathrm{P})\left(\mathrm{v}_{3}\right)$ which are to compare to what is reported in $\mathrm{Li}_{2} \mathrm{Co}\left(\mathrm{PO}_{4}\right)_{2}$ [38].

The Dq and B parameters can be determined from the position of the bands allowed in the absorption spectrum. Equations used and presented here are those described by Koring [39]. The band positions and the values calculated for Dq, B and 10Dq/B are given in Table 8.

\section{Ni(II)-complex}

The electronic spectrum of green $\mathrm{NaNi}\left(\mathrm{H}_{2} \mathrm{PO}_{3}\right)_{3} \cdot \mathrm{H}_{2} \mathrm{O}$ (Fig. 5c) is typical of the $\mathrm{Ni}^{+2}$ in high spin configuration. The lowest state of $\mathrm{Ni}^{+2}$ is ${ }^{3} \mathrm{~F}$ term, which can split in the terms ${ }^{3} \mathrm{~A}_{2 \mathrm{~g}},{ }^{3} \mathrm{~T}_{2 \mathrm{~g}}$ and ${ }^{3} \mathrm{~T}_{1 \mathrm{~g}}$ in a field with $\mathrm{O}_{\mathrm{h}}$ symmetry. Consequently the first and second spin allowed bands observed in the UV-Vis spectrum are assigned to $\left[{ }^{3} \mathrm{~A}_{2 \mathrm{~g}} \rightarrow{ }^{3} \mathrm{~T}_{2 \mathrm{~g}}\left({ }^{3} \mathrm{~F}\right)\right]\left(\mathrm{v}_{1}\right)$ and $\left[{ }^{3} \mathrm{~A}_{2 \mathrm{~g}} \rightarrow{ }^{3} \mathrm{~T}_{1 \mathrm{~g}}\left({ }^{3} \mathrm{~F}\right)\right]\left(\mathrm{U}_{2}\right)$. The third absorption band results from the spin allowed transition $\left[{ }^{3} \mathrm{~A}_{2 \mathrm{~g}} \rightarrow{ }^{3} \mathrm{~T}_{1 \mathrm{~g}}\left({ }^{3} \mathrm{P}\right)\right]\left(\mathrm{v}_{3}\right)$ and is usually found in the region $21.000-30.000 \mathrm{~cm}^{-1}$. The splitting is in agreement with the single crystal structure where $\mathrm{Ni}$ occupies two octahedral different positions [19]. Similar transitions's bands have been reported for $\mathrm{Ni}^{2+}$ in an octahedral oxygenated coordination [40]. The Dq and B parameters (Table 8) can be determined using the equations: $10 \mathrm{Dq}=\mathrm{v}_{1}$ and $\left[15 \mathrm{~B}+30 \mathrm{Dq}=\mathrm{v}_{2}+\mathrm{v}_{3}\right][32]$.

\section{Conclusions}

The new mixed phosphite $\mathrm{NaCd}\left(\mathrm{H}_{2} \mathrm{PO}_{3}\right)_{3} \cdot \mathrm{H}_{2} \mathrm{O}$ is isostructural to the known compounds in the series $\mathrm{NaM}\left(\mathrm{H}_{2} \mathrm{PO}_{3}\right)_{3} \cdot \mathrm{H}_{2} \mathrm{O}, \mathrm{M}=$ divalent $3 \mathrm{~d}$. Its crystals were made in solution and the crystal structure solved by X-Rays. IR spectra of the series $\mathrm{NaM}\left(\mathrm{H}_{2} \mathrm{PO}_{3}\right)_{3} \cdot \mathrm{H}_{2} \mathrm{O}, \mathrm{M}=$ 
$\mathrm{Mn}, \mathrm{Co}, \mathrm{Ni}, \mathrm{Mg}$ and $\mathrm{Cd}$ have been reported and commented. Electronic spectra of $\mathrm{NaM}\left(\mathrm{H}_{2} \mathrm{PO}_{3}\right)_{3} \cdot \mathrm{H}_{2} \mathrm{O}, \mathrm{M}=\mathrm{Mn}, \mathrm{Co}$, Ni have been recorded and the d-d transitions assigned.

\section{Acknowledgements}

The authors acknowledge the financial support from CNRST (Morocco) (URAC 19). The institutional research plan No.AVOZ10100521 of the Institute of Physics and the grant "Praemium Academiae" of the Academy of Sciences of the Czech Republic.

\section{Figures and Tables Captions}

Fig. 1: Projection of the crystal structure of $\mathrm{NaCd}\left(\mathrm{H}_{2} \mathrm{PO}_{3}\right)_{3} \cdot \mathrm{H}_{2} \mathrm{O}$ along the a axis. Polyhedrons colors key: cyan $\left[\mathrm{NaO}_{6}\right]$, yellow $\left(\mathrm{HPO}_{3}\right)$, green $\left[\mathrm{CdO}_{6}\right]$.

Fig. 2: Projection of the crystal structure along $\mathrm{c}$ with selected H-bonds as dashed lines.

Fig. 3: Perspective view of the the metal coordination in $\mathrm{NaCd}\left(\mathrm{H}_{2} \mathrm{PO}_{3}\right)_{3} \cdot \mathrm{H}_{2} \mathrm{O}$.

Figure 4a\&b: IR spectra from the series $\mathrm{NaM}\left(\mathrm{H}_{2} \mathrm{PO}_{3}\right)_{3} \cdot \mathrm{H}_{2} \mathrm{O}(\mathrm{M}=\mathrm{Mn}, \mathrm{Co}, \mathrm{Ni}, \mathrm{Zn}, \mathrm{Mg}$, Cd).

Figures 5a-c: UV-Vis absorption spectra of the phosphites $\mathrm{NaM}\left(\mathrm{H}_{2} \mathrm{PO}_{3}\right)_{3} \cdot \mathrm{H}_{2} \mathrm{O}(\mathrm{M}=\mathrm{Mn}$, Co and $\mathrm{Ni})$.

Tab. 1: Crystallographic data and details of X-ray diffraction analysis for $\mathrm{NaCd}\left(\mathrm{H}_{2} \mathrm{PO}_{3}\right)_{3} \cdot \mathrm{H}_{2} \mathrm{O}$.

Tab. 2: Atomic coordinates and equivalent isotropic displacement parameters for $\mathrm{NaCd}\left(\mathrm{H}_{2} \mathrm{PO}_{3}\right)_{3} \cdot \mathrm{H}_{2} \mathrm{O}$.

Tab. 3: Bond lengths $(\AA)$ and angles (degrees) for $\mathrm{NaCd}\left(\mathrm{H}_{2} \mathrm{PO}_{3}\right)_{3} \cdot \mathrm{H}_{2} \mathrm{O}$.

Tab. 4: Hydrogen-bonds for $\mathrm{NaCd}\left(\mathrm{H}_{2} \mathrm{PO}_{3}\right)_{3} \cdot \mathrm{H}_{2} \mathrm{O}(\AA$, deg. $)$. 
Tab. 5: Summary of the factor group analysis of $\mathrm{NaCd}\left(\mathrm{H}_{2} \mathrm{PO}_{3}\right)_{3} \cdot \mathrm{H}_{2} \mathrm{O}$.

Tab. 6a: Correlation scheme for the internal modes of $\mathrm{H}_{2} \mathrm{PO}_{3}{ }^{-}$in $\mathrm{NaCd}\left(\mathrm{H}_{2} \mathrm{PO}_{3}\right)_{3} \cdot \mathrm{H}_{2} \mathrm{O}$.

Tab. 6b: Correlation scheme for the internal modes of $\mathrm{H}_{2} \mathrm{O}$ in $\mathrm{NaCd}\left(\mathrm{H}_{2} \mathrm{PO}_{3}\right)_{3} \cdot \mathrm{H}_{2} \mathrm{O}$.

Tab. 7: Bands assignments $\left(\mathrm{cm}^{-1}\right)$ in the spectra from $\mathrm{NaM}\left(\mathrm{H}_{2} \mathrm{PO}_{3}\right)_{3} \cdot \mathrm{H}_{2} \mathrm{O}, \mathrm{M}=\mathrm{Mn}, \mathrm{Co}$, $\mathrm{Ni}, \mathrm{Zn}, \mathrm{Mg}$ and $\mathrm{Cd}$.

Tab. 8a-c: Bands assignments in the UV-Vis spectra of the phosphites $\operatorname{NaM}\left(\mathrm{H}_{2} \mathrm{PO}_{3}\right)_{3} \cdot \mathrm{H}_{2} \mathrm{O}, \mathrm{M}=\mathrm{Mn}, \mathrm{Co}$ and $\mathrm{Ni}$.

\section{References}

1. Sghyar, M.; Durand, J.; Cot, L. \& Rafiq, M. 1990, Acta Cryst. C46, 1378.

2. Ortiz-Avila, C. Y.; Squattrito, P. J.; Shieh, M. \& Clearfield, A. 1989, Inorg. Chem. 28 2608.

3. Durand, J.; Cot, L.; Sghyar M. \& Rafiq, M. 1992, Acta Cryst. C48, 1171.

4. Sghyar, M. ; Durand, J. ; Cot, L. \& Rafiq, M. 1991, Acta Cryst. C47, 8.

5. Loukili, M. ; Durand, J. ; Cot, L. \& Rafiq, M. 1988, Acta Cryst. C44, 6.

6. Tijani, N.; Durand, J. \& Cot, L. 1988, Acta Cryst. C44, 2048.

7. Loukili, M.; Durand, J.; Larbot, A.; Cot, L. \& Rafiq, M. 1991, Acta Cryst. C47, 477.

8. Loub, J.; Podlahova, J. \& Jecny, J. 1978, Acta Cryst. B34, 32.

9. Sghyar, M.; Durand, J. ; Cot, L. \& Rafiq, M. 1991, Acta Cryst. C47, 2515.

10. Morris, R. E.; Attfield, M. P. \& Cheetham, A. K. 1994, Acta Cryst. C50, 473.

11. Handlovic, M. 1969, Acta Cryst. B25, 227.

12. El Bali, B. \& Massa, W. 2002, Acta Cryst. E58, i29. 
13. Marcos, M. D.; Amoros, P.; Sapiňa, F.; Beltran, P. A.; Martinez, M. R. \& Attfield, P. J. 1993, Inorg. Chem. 32, 5044.

14. Sapiňa, F.; Gomez, P.; Marcos, M. D.; Amoros, P.; Ibaňez, R.; Beltran, D.; Navarro, R., Rillo \& C., Lera, F. 1989, Eur. J. Solid State Inorg. Chem. 26, 603.

15. Foulon, J. D.; Tijani, N.; Durand, J.; Rafiq M. \& Cot, L. 1993, Acta Cryst. C49, 849.

16. Foulon, J. D.; Durand, J. \& Cot, L. 1995, Acta Cryst. C51, 348.

18. Kratochvil, B.; Podlahova, J.; Habibpur, S.; Petricek, V. \& Maly, K. 1982, Acta Cryst. B38, 2436.

17. Chmelikova, R.; Loub, J. \& Petricek, V. 1986, Acta Cryst. C42, 1281.

19. Ouarsal, R., Thesis report, Faculty of Sciences „Dhar Mehraz” 2006.

20. Ouarsal, R.; Alaoui, A. T.; El Bali, B.; Lachkar, M. \& Harrison, W. T. 2002, Acta Cryst. E58, i23.

21. Ouarsal, R.; Alaoui, A. T.; Lachkar, M.; Dusek, M.; Fejfarova, K. \& El Bali, B. 2003, Acta Cryst. E59, i33.

22. Ouarsal, R.; Essehli, R.; Lachkar, M.; Zenkouar, M.; Dusek, M.; Fejfarova, K. \& El Bali, B. 2004, Acta Cryst. E60, i66.

23. Wei L, Hao-Hong C, Xin-Xin Y, Jing-Tai Z. Two Novel Transition-Metal Phosphite Compounds with 4-, 6- and 12-Membered Rings: Hydrothermal Syntheses, Crystal Structures and Magnetic Properties of Na2[M(HPO3)2] (M= Fe, Co). Eur J Inorg Chem 2005; 2005(5):946-951.

24. Hamchaoui F, Alonzo V, Roisnel T, Rebbah H, Le Fur E. Dipotassium trimanganese(II) tetrakis(hydrogenphosphite), K2Mn3(HPO3)4. Acta Cryst 2009; C65:i33-35. 
25. Cheng CC, Chang WK, Chiang RK, Wang SL. Synthesis and structural characterization of two cobalt phosphites: 1-D (H3NC6H4NH3) $\mathrm{Co}(\mathrm{HPO} 3) 2$ and 2-D (NH4)2Co2(HPo3)3. $\mathrm{J}$. Solid State Chem. 2010; 183:304-309.

26. Herrag L, El Bali B, Hammouti B, Ouarsal R, Elkadiri S, Lachkar M. Inhibition of steel corrosion in $\mathrm{HCl}$ media by phosphite compound. Pigm Resin Technol 2008; 37(3): $167-172$.

27. Herrag L, El Bali B, Lachkar M, Hammouti B. Investigation of adsorption and inhibitive effect of phosphite on corrosion of mild steel in hydrochloric acid media. Orient J Chem 2009; 25(2):265-272.

28. Agilent, CrysAlis PRO. Agilent Technologies, Yarnton, England 2010.

29. Altomare A, Burla MC, Camalli M, Cascarano GL, Giacovazzo C, Guagliardi A, Moliterni AGG, Polidori G, Spagna R. SIR97, J Appl Cryst 1999; 32:115-119.

- Palatinus L, Chapuis G. SUPERFLIP « a computer program for the solution of crystal structures by charge flipping in arbitrary dimensions». J Appl Cryst 2007; 40:786-790.

30. Petríček V, Dušek M, Palatinus L, Jana2006 Structure Determination Software Programs. Institute of Physics, Praha, Czech Republic 2007.

31. Brandenburg K, Putz H, DIAMOND Version 3. Crystal Impact GbR, Postfach 1251, D53002 Bonn, Germany 2005.

32. Reedijk J, van Leeuwen PWNM, Groeneveld WL. A semi-empirical energy-level diagram for octahedral Nickel(II) complexes; Recl Trav Chim Pay B 1968;87 :129-143.

33. Fateley, W.G.; Dollish, F. R.; McDevitt, N. T. \& Bentley, F. F.: Infrared and Raman Selection Rules for Molecules and Lattice Vibrations: the Correlation Method. Wiley: New York, 1972. 
34. Tanabe, Y., Sugano, S., J. Phys. Soc. Japan., 1954. 9. 753-766.

35. Chung UC, Mesa JL, Pizarro JL, Jubera V, Lezama L, Arriortua MI, Rojo T. Mn(HPO3): A new manganese (II) phosphite with a condensed structure. J Solid State Chem 2005; $178: 2913-2921$.

36. Boonchom B, Baitahe R.Synthesis and characterization of nanocrystalline manganese pyrophosphate Mn2P2O7. Mater Lett 2009; 63(26):2218-2220.

37. Kaoua S, Krimi S, Péchev S, Gravereau P, Chaminade JP, Couzi M, El Jazouli A. Synthesis, crystal structure, and vibrational spectroscopic and UV-visible studies of Cs2MnP2O7. J Solid State Chem 2013;198:379-385.

38. Glaum R, Gerber K, Schulz-Dobrick M, Herklotz M, Scheiba F, Ehrenberg H. Synthesis, structures and properties of the new lithium cobalt(II) phosphate Li4Co(PO4)2 J Solid State Chem 2012; 188:26-31.

39. Konig, E., Structure and Bonding., 1971. 9. 175-184.

40. Cotton FA, Wilkinson G, Murillo CA, Bochmann M. Advanced Inorganic Chemistry, 6th Ed, New York: John-Wiley and Sons $6^{\text {th }}$ Edition; 1999. 